\title{
Ultrastructural study of tergal and posterior sternal glands in Prorhinotermes simplex (Isoptera: Rhinotermitidae)
}

\author{
JAN ŠOBOTNÍK ${ }^{1}$, FRANTIŠEK WEYDA², ROBERT HANUS ${ }^{1,3 *}$ \\ ${ }^{1}$ Institute of Organic Chemistry and Biochemistry, Flemingovo nám. 2, CZ-166 10 Praha 6, Czech Republic; \\ e-mail: sobotnik@uochb.cas.cz \\ ${ }^{2}$ Institute of Entomology, Branišovská 31, CZ-370 05 České Budějovice, Czech Republic; e-mail: weyda@entu.cas.cz \\ ${ }^{3}$ Department of Zoology, Charles University, Viničná 7, CZ-128 44 Praha 2, Czech Republic
}

Key words. Ultrastructure, tergal gland, posterior sternal gland, secretory cell class 2, termite, Isoptera, Rhinotermitidae, Prorhinotermes simplex, imagoes

\begin{abstract}
In Prorhinotermes simplex, tergal glands are present on the last three tergites (from the 8th to the 10th) in imagoes of both sexes. In addition, males possess posterior sternal glands of the same structure on sternites 8 and 9 . The tergal and the posterior sternal glands consist of four cell types: class 1 and class 2 secretory cells, and class 3 cells with corresponding canal cells. The cytoplasm of class 1 cells contains smooth endoplasmic reticulum, elongated mitochondria and numerous microtubules. Apical parts of these cells are formed by dense and long microvilli with a central ductule. Class 2 cells contain predominantly lucent vacuoles (in females) or lipid droplets (in males). The structure of class 3 cells does not differ from class 3 cells found in other body par ts.
\end{abstract}

\section{INTRODUCTION}

Abdominal glands with specific sexual function occur in almost all representatives of Isoptera and Blattodea (Ampion \& Quennedey, 1981; Grassé, 1982; Sreng, 1984; Quennedey et al., 2004), but evidence about their presence in Mantodea is missing. In termites, the following glands were described: sternal, posterior sternal and tergal glands (Noirot, 1969; Ampion \& Quennedey, 1981; Grassé, 1982). The sternal glands produce predominantly trail pheromones although they secrete sexual pheromones in the imagoes of certain species. The tergal and the posterior sternal glands (if present) are involved in swarming, mate attraction and courtship behaviour (Noirot, 1969; Varma, 1980; Ampion \& Quennedey, 1981; Pasteels \& Bordereau, 1998; Quennedey et al., 2004; Peppuy et al., 2004).

The tergal glands in Isoptera are usually present on last two or three tergites, but they are secondarily reduced in many taxa. In Mastotermes darwiniensis Froggatt, the most primitive termite, eight glands (from the 3rd to the 10th tergite) are present, considered a plesiomorphic character (Ampion \& Quennedey, 1981). The tergal glands occur on posterior tergites in the number from 5 to 8 in the genus Macrotermes Holmgren as an apomorphy (Ampion \& Quennedey, 1981; Quennedey et al., 2004). The tergal glands are present in both sexes of primitive Isoptera, while only appearing in females in the advanced families Rhinotermitidae and Termitidae (Ampion \& Quennedey, 1981). The genus Prorhinotermes Silvestri is an exception to this rule, with the glands present in both sexes and much larger in females (Ampion \& Quennedey, 1981; Šobotník \& Hubert, 2003).
Males of several primitive genera have developed the posterior sternal glands, which occur on sternites 6 to 9 in Mastotermes darwiniensis, and 8 and 9 in Porotermes (Hagen), Stolotermes Hagen, and Prorhinotermes. In Mastotermes darwiniensis, they are present also in females on sternites 6 and 7. The tergal and the posterior sternal glands reveal a uniform structure (Ampion \& Quennedey, 1981). According to observations made on females of Cornitermes bequaerti Emerson, tergal glands are composed of class 1, 2 and 3 cells (Bordereau et al., 2002). Tergal and posterior sternal glands of unique structure were found on sternites 6 and 7 in females of Macrotermes annandalei (Silvestri), formed by class 3 cells extending to subcuticular pouches (Quennedey et al., 2004).

The only identified compound produced by the tergal glands in termites is $(3 Z, 6 Z, 8 E)$-dodeca-3,6,8-trien-1-ol, acting in Cornitermes bequaerti as a sexual pheromone (Bordereau et al., 2002). The same substance is produced by the sternal gland in a number of termite species as a trail pheromone and may also act as a sexual pheromone but in higher concentrations (for a review see Pasteels \& Bordereau, 1998).

The function of the tergal glands has been described more precisely in cockroaches. Female glands produce male attractants (Sreng, 1984; 1985), while those in males produce two successively active chemical signals: sexual pheromones for attracting females and an aphrodisiac involved in mating (Sreng, 1984). Female cockroaches are known to feed on male tergal gland secretions; male specific proteins serving as food for females were described in Leucophaea maderae (Fabricius) (Korchi et al., 1998; Cornette et al., 2001, 2002, 2003).

\footnotetext{
* Corresponding author; e-mail: robert@uochb.cas.cz.
} 
Prorhinotermes is an exceptional genus among advanced termites because of many peculiar characters (for a review see Quennedey \& Deligne, 1975; Štys \& Šobotník, 1999). Among others, both sexes possess well developed tergal glands and posterior sternal glands are only present in males. The aim of this paper is to describe for the first time the fine structure of the tergal and the posterior sternal glands in swarming imagoes of both sexes.

\section{MATERIAL AND METHODS}

Imagoes of both sexes of Prorhinotermes simplex (Hagen, 1858) originated from a colony collected by Dr. J. Křeček in Soroa (Piñar del Rio, Cuba) in December 1964, and since then kept in the laboratory at $26 \pm 1{ }^{\circ} \mathrm{C}$.

Posterior dorsal parts (sternal in the case of the posterior sternal glands) of termite abdomens were fixed in a mixture of $2 \%$ glutaraldehyde and 2.5\% formaldehyde (Polysciences, EM Grade) in $0.1 \mathrm{M}$ phosphate buffer at laboratory temperature. After washing in pure $0.1 \mathrm{M}$ phosphate buffer, tissues were postfixed in $2 \%$ osmium tetroxide in the same buffer for $2 \mathrm{~h}$, washed in bidistilled water and dehydrated in $50 \%, 75 \%$ and absolute ethanol. Subsequently tissues were embedded into Spurr resin (standard mixture). Semithin and ultrathin sections were made with a Reichert Ultracut ultramicrotome. Semithin sections were stained with methylene blue and studied in an Axioskop Weiss optical microscope (with Sony Cyber-shot digital camera). Ultrathin sections were stained with uranyl acetate and lead citrate (standard recipe) and studied in a Jeol 1010 transmission electron microscope.

For the SEM study, living imagoes were placed into absolute ethanol, dried by the critical point method, glued onto an aluminium holder, sputter-coated with gold and observed in a Jeol 6300 electron microscope.

\section{RESULTS}

Both sexes are usually equipped with three tergal glands situated in the anterior part of the 8th, the 9th and the 10th tergite. In addition, males possess two posterior sternal glands (on the 8th and the 9th sternite). A surprising variability in the number of male glands occurs; in one male four tergal (on tergites 7 to 10) glands were observed (Fig. 1), in another one three posterior sternal glands (on sternites 7 to 9) were found (Fig. 7).

The surface of the cuticle covering the glands differs from that on other body parts (based on SEM observation). Small depressions of epicuticle are more marked and numerous on the cuticle covering the glands as well as the openings of the canals corresponding to class 3 cells (Fig. 14). These depressions do not correspond with the deeper structure of the cuticle. The angular pattern of the cuticle corresponds to the shapes of epidermal/glandular cells producing the cuticle during moulting (Fig. 14).

\section{Male imago}

Tergal and posterior sternal glands reveal identical structure (compare Figs 2 and 8). The height of the secretory epithelium is up to $25 \mu \mathrm{m}$ in the centre and about 10 $\mu \mathrm{m}$ in the margins of both tergal and posterior sternal glands. Secretory cells class 1, 2, and 3 (according to Noirot \& Quennedey, 1974) were found to form tergal and posterior glands. Secretory cells class 1 and 2 are equally numerous while class 3 cells are less abundant. Secretory cell class 1

These cells are columnar with extended apices and are located predominantly close to the cuticle (Figs 2, 8). A few basal invaginations occur at the contact area between class 1 cells and the basement membrane. Nuclei are irregular, up to $12 \mu \mathrm{m}$ in the largest dimension when flat.

The cytoplasm contains a large amount of smooth endoplasmic reticulum (SER) (Figs 4, 10). It is formed by tubules about $35 \mathrm{~nm}$ thick. Smaller amounts of rough endoplasmic reticulum (RER) are scattered among SER (Fig. 4). Electron dense granules are frequently present in the cytoplasm (Figs 9, 10), sometimes partially decomposed into myelin figures (Fig. 9). Microvilli are dense and their length varies from 1 to $4 \mu \mathrm{m}$. The diameter of a microvillus is about $110 \mathrm{~nm}$. Microvilli are always equipped with a central ductule (about $40 \mathrm{~nm}$ in diameter; Fig. 3). Microvilli are in direct contact with the cuticle (Figs 2, 3, 9, 12, 15). The cytoplasm contains a moderate amount of microtubules (Fig. 10) oriented predominantly apico-basally. Mitochondria are elongated (up to $2 \mu \mathrm{m}$ long and up to $0.5 \mu \mathrm{m}$ thick) of a moderately dense matrix and flat cristae (Fig. 4). The basement membrane is formed by a single lamina (about $60 \mathrm{~nm}$ thick). Locally it contains collagen fibres, then its thickness increases up to $300 \mathrm{~nm}$ (see Fig. 16 for a similar situation in female).

The cuticle overlying the glands reveals only a slight modification. It is formed by an endocuticle (about $2 \mu \mathrm{m}$ thick), an exocuticle (about $0.5 \mu \mathrm{m}$ thick) and a thin epicuticle (not shown). Inside the endo- and exocuticle there are enlarged pore canals (with a single pore canal filament), which contain fine particles of secretion (Fig. 3). The widest pore canals are in the endocuticle adjacent to exocuticle (not shown).

The connection between neighbouring cells is formed by an apical desmosome followed by a long septate junction (Fig. 10). Membranes are free only in the basal part.

\section{Secretory cell class 2}

Class 2 cells are oval in shape, situated among class 1 cells (Fig. 2). They do not reach the cuticle. The class 2 cells contact the basement membrane and possess numerous shallow basal invaginations (about $0.5 \mu \mathrm{m}$ deep). They are attached to the basement membrane by several hemidesmosomes (Fig. 6).

Nuclei are rounded, situated centrally, usually about 7 $\mu \mathrm{m}$ in the largest dimension. A relatively voluminous cytoplasm contains moderate amount of RER and a large number of free ribosomes. SER was observed only rarely. Electron dense (probably proteinaceous) granules often occur, many of them are partially decomposed by myelin figures. Mitochondria are moderately abundant throughout the whole cell. They are cylindrical in shape (from 0.7 to $1.2 \mu \mathrm{m}$ in the largest diameter). Their cristae are tubular; the matrix heavy dense (not shown). The class 2 cells contain numerous inclusions, which strongly resemble lipid droplets (e.g. they are not delimited by a membrane). They are homogenous, moderately electron 
dense. The droplets are always spherical (1-2 $\mu \mathrm{m}$ in diameter), often interconnected (Fig. 2). The myelin figures may penetrate into the droplets (Fig. 5). Class 2 cells have no junction with other cells.
Secretory cell class 3

Class 3 secretory cells are much smaller than the other cell types, up to $15 \mu \mathrm{m}$ in the largest dimension. They are intercalated among the cells of other types (Fig. 12). Apical microvilli (from 0.5 to $2 \mu \mathrm{m}$ long) are grouped
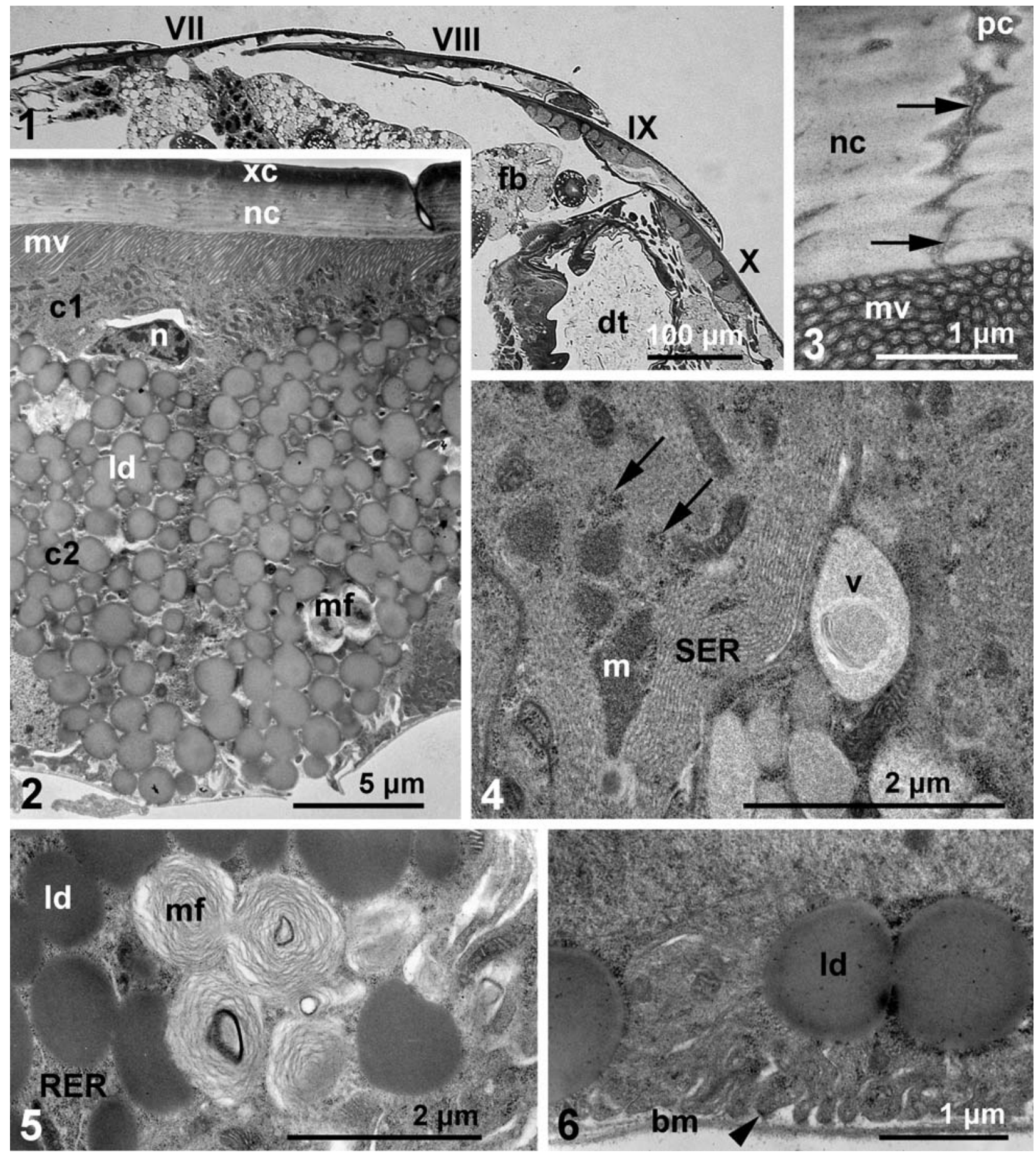

Figs 1-6: Prorhinotermes simplex (ultrastructure of male tergal glands). 1 - view on the semithin section of tergal part of posterior abdomen of anomalous male with four tergal glands; 2 - general view of the gland; 3 - apical part of the gland. Note the microvilli with central ductule and enlarged pore canal filled with secretion. Arrows mark pore canal filament; 4 - cytoplasm of class 1 cell. Arrows mark groups of ribosomes; 5 - myelin figures in the cytoplasm of a class 2 cell. Note the disintegration of lipid droplet by the myelin figure; 6 - basal part of class 2 cell. Note basal invaginations. Arrowhead marks the hemidesmosome. Lettering: VII.-X. - tergites from the seventh to the tenth; bm - basement membrane; $\mathrm{c} 1$ - secretory cell class 1 ; c 2 - secretory cell class 2 ; dt - digestive tract; $\mathrm{fb}$ - fat body; $\mathrm{ld}$ - lipid droplet; $\mathrm{m}$ - mitochondria; $\mathrm{mf}$ - myelin figure; $\mathrm{mv}$ - microvilli; $\mathrm{n}$ - nucleus; $\mathrm{nc}$ - endocuticle; $\mathrm{pc}$ pore canal; RER - rough endoplasmic reticulum; SER - smooth endoplasmic reticulum; v - vacuole; xc - exocuticle. 
about the receiving canal (see Fig. 13 for similar situation in female). The receiving canal is formed by several layers (three to five) of a porous epicuticle. Its diameter is about $0.5 \mu \mathrm{m}$; the inner space is about $150 \mathrm{~nm}$ wide (see Fig. 13 for similar situation in female). Nuclei are irregular, up to $7 \mu \mathrm{m}$ in the largest dimension. Mitochondria are abundant; their matrix is moderately dense. Their size ranges from 0.5 to $1 \mu \mathrm{m}$.

The secretory vacuoles are concentrated predominantly about the cell apex. Their size varies from 0.5 to $2 \mu \mathrm{m}$. Individual vacuoles differ in their density (lucent to moderately dense) as a result of a different amount of fine electron dense particles (about $15 \mathrm{~nm}$ in size) (see Fig. 13 for similar situation in female). Fusion of vacuoles is a common process; even vacuoles of different densities may fuse.

The cytoplasm contains numerous Golgi apparatuses (up to $2 \mu \mathrm{m}$ in size), which produce lucent vacuoles about $0.5 \mu \mathrm{m}$ in diameter. RER is present in large amounts throughout the cytoplasm and produces vacuoles (about $0.5 \mu \mathrm{m}$ in diameter) of higher density.

The canal cells are very small; only rarely they contain some organelles (mitochondria, RER). Their cytoplasm forms a thin layer covering the cuticular canal. Nuclei are irregular, often elongated, with numerous chromatin aggregates. The conducting canal is formed by outer and inner epicuticle (Fig. 11). The total thickness of the cuticle is about $70 \mathrm{~nm}$.
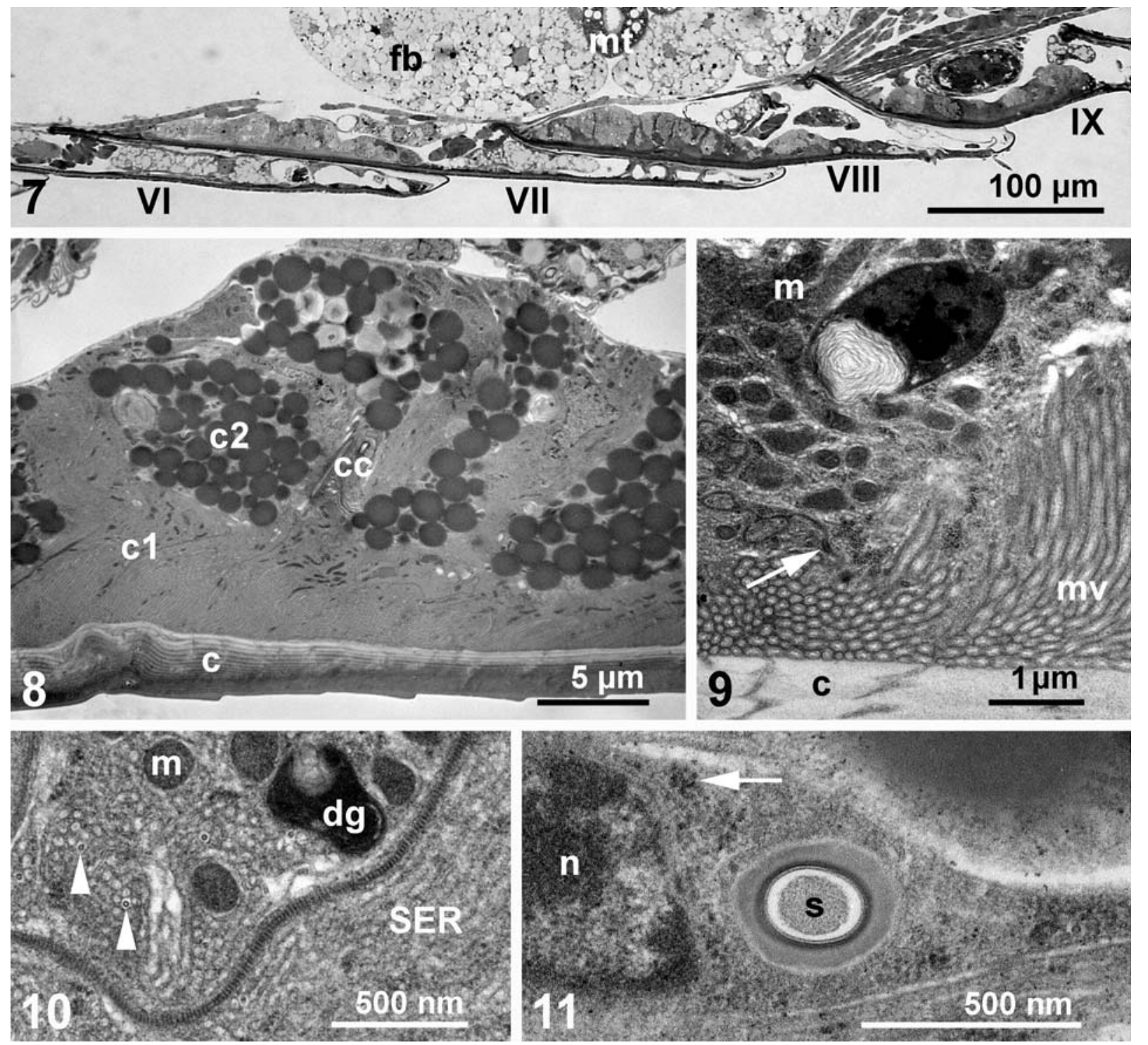

Figs 7-11: Prorhinotermes simplex (ultrastructure of male posterior sternal glands). 7 - view on the semithin section of sternal part of posterior abdomen of anomalous male with three posterior sternal glands; 8 - general view of the gland; 9 - apical part of class 1 cell. Note the electron dense granule partially decomposed into myelin figure. Arrow marks a desmosome; 10 - septate junction connecting neighboring cells class 1 . Arrowheads mark microtubules; 11 - canal cell. Arrow marks group of free ribosomes. Lettering: VI.-IX. - sternites from the sixth to the ninth; $\mathrm{c}$ - cuticle; cc - canal cell; c1 - secretory cell class 1 ; c2 - secretory cell class 2; $\mathrm{dg}$ - electron dense granule; $\mathrm{fb}$ - fat body; $\mathrm{m}$ - mitochondria; $\mathrm{mt}$ - Malpighian tubule; $\mathrm{mv}$ - microvilli; $\mathrm{n}$ - nucleus; $\mathrm{s}-$ secretion of class 3 cell inside the conducting canal; SER - smooth endoplasmic reticulum. 

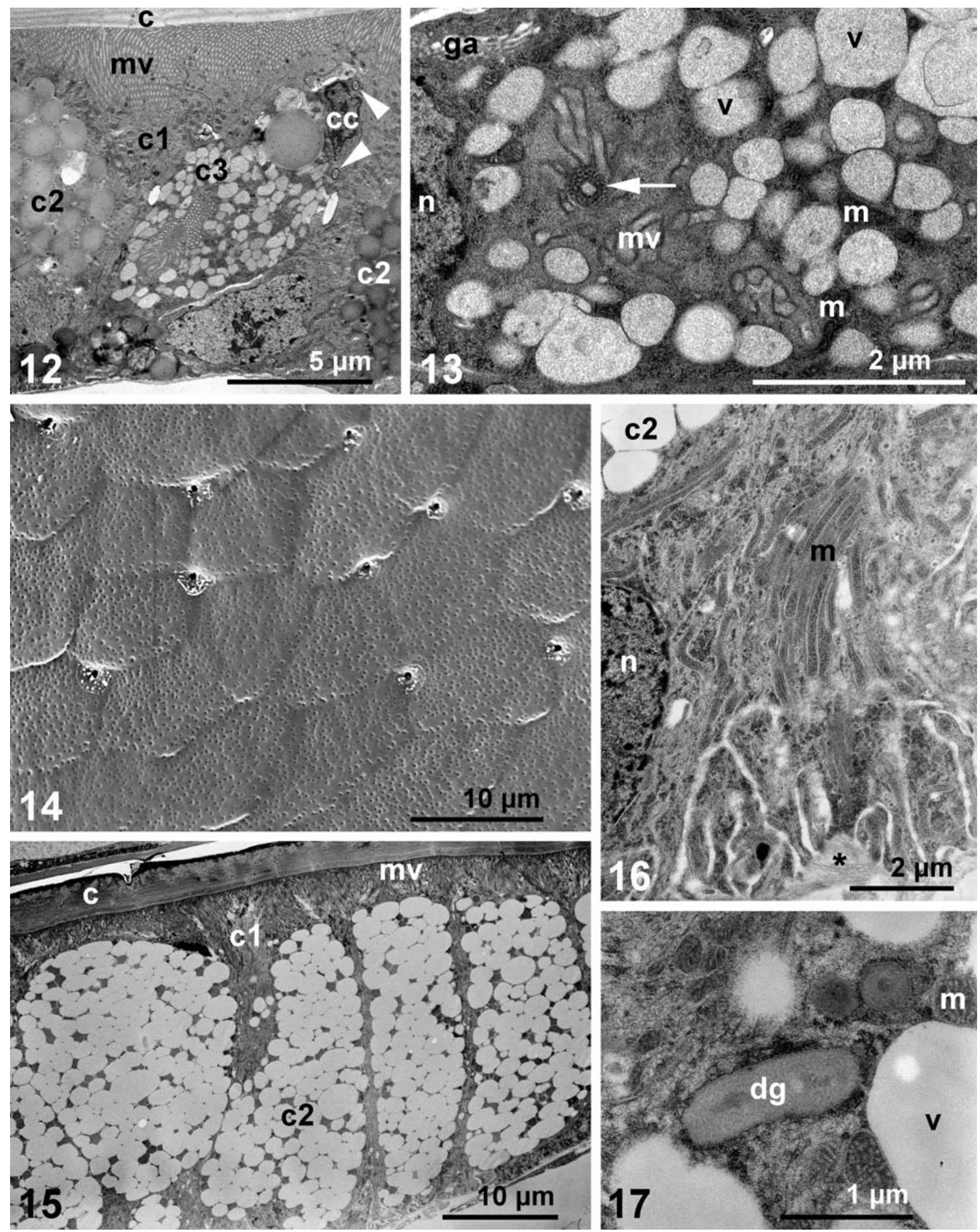

Figs 12-17: Prorhinotermes simplex (ultrastructure of male and female tergal glands). 12 - general view of the gland with class 3 cell in male. Arrowheads mark sections through the conducting canal; 13 - central part of class 3 secretory cell in female. Arrow marks the receiving canal; 14 - SEM figure of cuticle covering the gland in female; 15 - general view of the gland in female. Note the limited contact of class 2 cells with the basement membrane; 16 - basal part of class 1 cell in female. Asterisk marks basement membrane containing collagen fibres. Note the elongated mitochondria associated with basal invaginations; 17 - formation of electron dense granules by action of rough endoplasmic reticulum within the class 2 cell in female. Note the mitochondria with tubular cristae. Lettering: $\mathrm{c}$ - cuticle; cc - canal cell; $\mathrm{c} 1$ - secretory cell class 2 ; $\mathrm{c} 2$ - secretory cell class 2 ; c3 - secretory cell class 3 ; dg dense granule; ga - Golgi apparatus; $\mathrm{m}$ - mitochondria; $\mathrm{mv}$ - microvilli; $\mathrm{n}$ - nucleus; $\mathrm{v}$ - vacuole. 
The connection between class 3 cells and corresponding canal cells is formed by a septate junction only.

\section{Female imago (differences from male)}

The tergal glands of females are organized similarly to those in males but considerable differences occur at the ultrastructural level. The secretory epithelium is thicker, its height ranging from $40 \mu \mathrm{m}$ in the gland centre to about $20 \mu \mathrm{m}$ in the periphery.

Secretory cells class 1 are sandglass-shaped, running from the cuticle to the basement membrane (Fig. 15). The extent of basal invaginations is much larger (Fig. 16). Small lucent vacuoles (about $200 \mathrm{~nm}$ in diameter) observed in the cytoplasm originate as pinocytotic vesicles separated from basal invaginations. Microtubules are more numerous in females, while the amount of SER and RER is lower. Electron dense granules were observed only rarely. The microvilli are in general longer (from 1 to $7 \mu \mathrm{m}$ long). Mitochondria are more elongated, their width usually does not exceed $0.2 \mu \mathrm{m}$ (Fig. 16).

The class 2 cells have a limited contact with the basement membrane; basal invaginations are always lacking. The volume of the cytoplasm is low. Secretory cells class 2 contain large amounts of equal-sized lucent vacuoles. They are about $2 \mu \mathrm{m}$ in diameter and are angulated as a result of their crowding (Fig. 15). These vacuoles are always delimited by a membrane. Mitochondria (from 0.7 to $1.2 \mu \mathrm{m}$ in diameter) are rounded but irregular due to their position among the crowded vacuoles. Smaller amounts of RER occur in marginal parts of the cells and SER is lacking completely. Electron dense granules often present in the cytoplasm are formed by RER (Fig. 17). Small myelin figures are rarely present inside the lucent vacuoles.

Class 3 secretory cells do not differ from those observed in males.

\section{DISCUSSION}

The variability in number of both glands in males is hard to explain. It may be linked with the origin of imagoes from different instars as described by Roisin (1988). We fixed only one type of glands (either the tergal or the posterior sternal) from each individual. Two males from 12 investigated were found to differ in the number of glands compared to others.

In Blattodea and Isoptera, the tergal glands generally consist of secretory cells class 1, 2 and 3 (Sreng, 1984; 1985; Bordereau et al., 2002). Our data on P. simplex support these results, in contrast with Ampion \& Quennedey (1981) who do not refer the presence of class 2 cells in the tergal glands of $P$. simplex and Cornitermes bequaerti. Apart from cellular composition, the tergal and the posterior sternal glands are organised similarly to the modal situation in termites (Noirot, 1969; Ampion \& Quennedey, 1981). Posterior sternal glands of different structure were found in Macrotermes annandalei (Quennedey et al., 2004).

The secretory cells class 1 are developed similarly in both sexes of $P$. simplex. They contain predominantly a considerable amount of SER. SER is present in higher quantities in males in which it even occurs in class 2 cells. The high amount of SER in the tergal gland cells is in agreement with other observation on pheromone producing glands. SER is a common organelle involved in the production of small, non-proteinaceous molecules (such as lipidic substances, hydrocarbons or quinones), and its absence in pheromone producing organs is rather an exception (Eisner et al., 1964; Percy, 1974; LalanneCassou et al., 1977; Billen, 1987; Vinson, 1994; Sánchez et al., 1998; Wenseleers et al., 1998; Billen et al., 1999; 2000; reviewed by Percy-Cunningham \& MacDonald, 1987; Tillman et al., 1999). Male secretory cells class 2 may provide lipidic substances serving as a substratum for further steps of biosynthesis in the cells class 1 . The presence of a higher amount of microtubules in class 1 cells in females may be related with the larger size of secretory cells. Such cells may need the strengthening analogously to the situation in the tergal glands of cockroaches, in which specific cells with a support function occur (microtubule cells; Sreng, 1985).

Secretory cells class 2 represent modified oenocytes (Quennedey, 1998) and their presence is known only from termite sternal (Quennedey, 1971; 1998; Noirot \& Quennedey, 1974) and tergal glands (Bordereau et al., 2002) and from the sternal and tergal glands in cockroaches (Sreng, 1984; 1985). The structure of class 2 cells differs between sexes of $P$. simplex, e.g. the basal invaginations are present in males, but they are lacking completely in females. The shape of mitochondria differs in females due to crowding of lucent vacuoles. The major difference consists though in the nature of the inclusions. In males, the inclusions seem to be predominantly lipid droplets located freely in the cytoplasm, while in females they are made of an electron lucent material enclosed in membrane bounded vacuoles. We expect that the composition of lipid droplets in the tergal and the posterior sternal glands in males differs from lipids in the fat body: droplets in secretory cells class 2 are much denser (compare in both Fig. 1 and Fig. 7). Similarly to Bordereau et al. (2002), we did not observe any direct transfer of secretion from class 2 into class 1 cells, but it is very probable, because class 2 cells are separated from the cuticle by a continuous layer of class 1 cells. This fact may indicate a cyclical activity of transporting mechanisms, which may occur only in certain situations (e.g. shortly before swarming?).

Secretory cells class 3 reveal the same structure in both sexes. They do not differ from the other class 3 cells scattered all over the body. Therefore we expect that they do not play an important role in the tergal gland secretory function.

Our results are consistent with those obtained by Bordereau et al. (2002) in Cornitermes bequaerti; the tergal glands are developed similarly in both species in spite of about twice larger size of secretory cells in females of $P$. simplex. The glands in males of $P$. simplex differ in structure from female glands of both species ( $P$. simplex and $C$. bequaerti), so we expect that also the produced secre- 
tions will be more resembling in females of both species than in $P$. simplex males and females.

ACKNOWLEDGEMENTS. We are grateful to the staff of the Laboratory of Electron Microscopy (Institute of Parasitology, Academy of Sciences of the Czech Republic) for their kind help. Our thanks belong also to J. Pflegerová (Institute of Entomology, Academy of Sciences of the Czech Republic) for the preparation of samples for TEM. We thank J. Hubert (Institute of Crop Protection, Prague) for his help with light microscopy. We are grateful to A. Quennedey and C. Bordereau (Université de Bourgogne, Dijon, France) for critical reading of the manuscript. We thank R. Macková (Praha) for English review. J. Šbotník and R. Hanus thank to Z4 0550506 project realized in IOCB, Prague.

\section{REFERENCES}

Ampion M. \& Quennedey A. 1981: The abdominal epidermal glands of termites and their phylogenetic significance. Syst. Assoc. (Spec. Vol.) 19: 249-261.

BiLlen J. 1987: Morphology and ultrastructure of the exocrine glands in social Hymenoptera. In Eder J. \& Rembold H. (eds): Chemistry and Biology of Social Insects. J. Peperny Verlag, München, pp. 81-84.

Billen J., Gobin B. \& Iто F. 1999: Fine structure of the postpygidial gland in Aenictus army ants. Acta Zool. 80: 307-310.

Billen J., Ito F., Tsuj K., Schoeters E., Maile R. \& Morgan E. D. 2000: Structure and chemistry of the Dufour gland in Pristomyrmex ants (Hymenoptera, Formicidae). Acta Zool. 81: $159-166$

Bordereau C., Cancello E.M., Sémon E., Courrent A. \& QueNNEDEY B. 2002: Sex pheromone identified after Solid Phase Microextraction from tergal glands of female alates in Cornitermes bequaerti (Isoptera, Nasutitermitidae). Insectes Soc. 49: 209-215.

Cornette R., Farine J.P., Quennedey B. \& Brossut R. 2001: Molecular characterization of a new male adult putative calycin specific to tergal aphrodisiac secretion in the cockroach Leucophaea maderae. FEBS Letters 507: 313-317.

Cornette R., Farine J.P., Quennedey B., Rivire S. \& Brossut R. 2002: Molecular characterization of Lma-p54, a new epicuticular surface protein of the cockroach Leucophaea maderae (Dictyoptera, Oxyhaloinae). Insect Biochem. Mol. Biol. 32: $1635-1642$.

Cornette R., Farine J.P., Abed-Vieillard D., Quennedey B. \& BRossut R. 2003: Molecular characterization of a malespecific glycosyl hydrolase, Lma-p72, secreted on to the abdominal surface of the Madeira cockroach Leucophaea maderae (Blaberidae, Oxyhaloinae). Biochem. J. 372: 535-541.

Eisner T., McHenry F. \& Salpeter M.M. 1964: Defence mechanisms of Arthropods. XV. Morphology of the quinoneproducing glands of a tenebrionid beetle (Eleodes longicornis Lec.). J. Morphol. 115: 355-399.

Grassé P.-P. 1982: Termitologia. Vol. 1. Masson, Paris, 676 pp. Korchi A., Farine J.-P. \& Brossut R. 1998: Characterization of two male-specific polypeptides in the tergal glands secretion of the cockroach Leucophaea maderae (Dictyoptera, Blaberidae). Insect Biochem. Mol. Biol. 28: 113-120.

Lalanne-Cassou B., Percy J. \& McDonald J.A. 1977: Ultrastructure of sex pheromone gland cells in Lobesia bothrana Den \& Schiff. (Lepidoptera, Olethreutidae). Can. J. Zool. 55: 672-680.
NoIrot C. 1969: Glands and secretions. In Krishna K. \& Weesner F.M. (eds): Biology of Termites. Vol. 1. Academic Press, New York, pp. 89-123.

Norrot C. \& QuenNedeY A. 1974: Fine structure of insect epidermal glands. Annu. Rev. Entomol. 19: 61-80.

Pasteels J.M. \& Bordereau C. 1998: Releaser pheromones in termites. In Van der Meer R.K., Breed M.D., Espelie K.E. \& Winston M. L. (eds): Pheromone Communication in Social insects: Ants, Wasps, Bees and Termites. Westview Press, Boulder, pp. 193-215.

Peppuy A., Robert A. \& Bordereau C. 2004: Species-specific sex pheromones secreted from new sexual glands in two sympatric fungus-growing termites from northern Vietnam, Macrotermes annandalei and M. barneyi. Insectes Soc. 51: 91-98

Percy J.E. 1974: Ultrastructure of sex pheromone gland cells and cuticle before and during release of pheromone in female eastern spruce budworm Choristoneura fumiferana (Clem.) (Lepidoptera, Tortricidae). Can. J. Zool. 52: 695-705.

Percy-Cunningham J.E. \& MacDonald J.A. 1987: Biology and ultrastructure of sex pheromone-producing glands. In Prestwich G.D. \& Blomquist G.J. (eds): Pheromone Biochemistry. Academic Press, London, pp. 27-75.

QuenNEDEY A. 1971: Les glandes exocrines des termites. Organisation de la glande sternale des Rhinotermitidae. Etude ultrastructurale preliminaire. C. R. Acad. Sci. 273: 376-379.

QuenNedey A. \& Deligne J. 1975: L'arme frontale des soldats de termites. I. Rhinotermitidae. Insectes Soc. 22: 243-267.

QuENNEDEY A. 1998: Insect epidermal gland cells: ultrastructure and morphogenesis. In Locke M. (ed.): Microscopic Anatomy of Invertebrates. Vol. 11A: Insecta. Wiley-Liss, New York, pp. 177-207.

Quennedey A., Peppuy A., Courrent A., Robert A., Everaerts C. \& Bordereau C. 2004: Ultrastructure of posterior sternal glands of Macrotermes annandalei (Silvestri); new member of the sexual glandular set found in termites (Insecta). J. Morphol. 262: 683-691.

RoISIN Y. 1988: Morphology, development and evolutionary significance of the working stages in the caste system of Prorhinotermes (Insecta, Isoptera). Zoomorphology 107: 339-347.

Sánchez P.A., SÁnchez F., Jaffé K. \& Caetano F.H. 1998: Ultrastructure of the gland responsible for the synthesis of an aggregation pheromone in Rhynchophorus palmarum (L.) (Coleoptera: Curculionidae). Coleop. Bull. 52: 297-305.

SRENG L. 1984: Morphology of the sternal and tergal glands producing the sexual pheromones and the aphrodisiacs among the cockroaches of the subfamily Oxyhaloinae. J. Morphol. 182: 279-294.

SRENG L. 1985: Ultrastructure of the glands producing sex pheromones of the male Nauphoeta cinerea (Insecta, Dictyoptera). Zoomorphology 105: 133-142.

Šobotní J. \& Hubert J. 2003: The morphology of the exocrine glands of Prorhinotermes simplex (Isoptera: Rhinotermitidae) and their ontogenetical aspects. Acta Soc. Zool. Bohem. 67: 83-98.

ŠTYs P. \& Šobotník J. 1999: Comments on classifications of insect ontogenies, and occurence of proneometabolous wing development in termite genus Prorhinotermes (Hexapoda: Isoptera). Acta Soc. Zool. Bohem. 63: 483-492.

Tillman J.A., Seybold S.J., Jurenka R.A. \& Blomquist G.J. 1999: Insect pheromones - an overview of biosynthesis and endocrine regulation. Insect Biochem. Mol. Biol. 29: 481-514.

VARMA R.V. 1980: Tergal glands and its probable role in sex attraction in the termite, Postelectrotermes nayari. Proc. Indian Acad. Sci., Anim. Sci. 89: 551-556. 
VINSON S.B. 1994: Ultrastructure of the mesosomal gland of Xylocopa micans (Hymenoptera: Anthophoridae) associated with pheromone release. Int. J. Insect Morphol. Embryol. 23: 243-252.
Wenseleers T., Schoeters E., Billen J. \& Wehner R. 1998: Distribution and comparative morphology of the cloacal gland in ants (Hymenoptera: Formicidae). Int. J. Insect Morphol. Embryol. 27: 121-128.

Received May 13, 2004; revised August 18, 2004; accepted September 9, 2004 